\title{
CROP ROTATION WITH BRASSICAS REDUCES PHYTOPHTHORA POPULATIONS IN POTATO SOIL
}

\author{
L-H. CHEAH, A.T. MARSH, D. HEDDERLEY and R.E. FALLOON \\ Crop \& Food Research, Private Bag 11600, Palmerston North, New Zealand \\ Corresponding author: cheahl@crop.cri.nz
}

\begin{abstract}
A long-term trial (5 years) is being conducted at a commercial property on land that has a history of high incidence and severity of soil-borne diseases. Five rotational crops (potato, pasture, brassica, cereal and squash) are being tested for their effects on pathogen inoculum. Soil applications of metalaxyl fungicide are used as a standard treatment for comparison. Soil samples are taken before and after each crop rotation cycle and plated on agar media for microbial enumeration, to study the changes in fungal pathogen populations. After three growing seasons, rotational treatment of potato and cereal + BQ Mulch (Brassica crop) reduced the level of Phytophthora and other (unidentified) fungi compared with the same rotation without BQ Mulch. Metalaxyl has had no effect on the soil levels of Phytophthora and Pythium spp.

Keywords: crop rotation, brassica crop, biofumigant, soil-borne pathogens, potato.
\end{abstract}

\section{INTRODUCTION}

Soil-borne fungal diseases, caused by Phytophthora, Pythium and Fusarium spp., are limiting potato production in the Manawatu region of New Zealand (Cheah \& Marsh 2006). Pink rot (caused by Phytophthora erythroseptica) and dry rot (caused by Fusarium spp.) are major problems in this region. In a long-term (5 years) field trial, the effect of rotational crops (wheat, barley, maize, squash and potatoes) and BQ Mulch (brassica crop) on soil-borne populations of fungal pathogens are being studied. These crops were selected because during a survey in 2004 growers said they need some cash income from these crops as well as acting as rotational crops (Cheah \& Marsh 2005). BQ Mulch (brassica crop) was included because it contains high level of glucosinolates and has been shown to significantly reduce Phytophthora inoculum levels and root rot severity on pawpaw (Vawdrey et al. 2002). The aim is to establish best crop rotation practice for the suppression of soil-borne pathogens in potato soil. By the end of the first year of the long-tern trial, there was a general reduction in Phytophthora spp. inoculum in the soil after the crop rotation but there was no significant difference between treatments (Cheah \& Marsh 2006).

This paper reports on data collected up to the end of the third full year of the trial.

\section{MATERIALS AND METHODS}

A long-term ( 5 year) trial is being carried out at a potato grower's property (Opiki in the Manawatu region). The site was chosen as it had a history of severe pink rot occurrence in harvested potatoes. Five rotational crops (potato, pasture, brassica, cereal and squash) are being tested for their effects on populations of soil-borne pathogens. Table 1 outlines the six different rotation treatments applied in the trial, and the annual cycles of crops being grown. Treatment 1 is the "control" treatment, consisting of five continuous annual spring plantings of potatoes followed by winter pasture. Plots within this treatment are split in half, with one half being treated with metalaxyl granules at 
$2.5 \mathrm{~g} /$ /itre water (Ridomil 5G) applied at the time of potato planting and the other half receiving no metalaxyl application. Treatment 1 without metalaxyl provides a baseline. BQ Mulch is a mixture of Brassica rapa and B. napus.

TABLE 1: The six rotation treatments used for the 5-year trial that investigated changes in soil-borne pathogen levels.

\begin{tabular}{lcccccc}
\hline Treatment & 1 & 2 & 3 & 4 & 5 & 6 \\
\hline Season 1 & Potato & Cereal & Squash & Potato & Pasture & Pasture \\
Winter & Pasture & BQM $^{1}$ & BQM & Cereal & Pasture & Pasture \\
Season 2 & Potato & Potato & Onion & Potato & Pasture & Pasture \\
Winter & Pasture & Cereal/BQM & BQM & Cereal & BQM & Pasture \\
Season 3 & Potato & Potato & Potato & Potato & Potato & Pasture \\
Winter & Pasture & BQM & BQM & Cereal & Cereal & BQM \\
Season 4 & Potato & Potato & Potato & Onion & Potato & $\begin{array}{c}\text { Potato/ } \\
\text { metalaxyl } \\
\text { Winter }\end{array}$ \\
Pasture & Cereal/BQM & BQM & Cereal & Cereal & BQM \\
Season 5 & Potato & Potato & Potato & Squash & Potato & $\begin{array}{c}\text { Potato/ } \\
\text { metalaxyl }\end{array}$ \\
\hline
\end{tabular}

${ }^{1} \mathrm{BQM}=\mathrm{BQ}$ mulch.

The trial layout is a randomised block design of six treatments, replicated six times. Each plot is $10 \mathrm{~m}$ long and $7.2 \mathrm{~m}$ wide and, during the potato phase, is planted with seven rows of potatoes with $90 \mathrm{~cm}$ spacing between rows. Soil samples were taken twice annually, first prior to planting of the new season's potato crop and again at the time of potato harvest. Two soil samples per plot were taken from each area, at intersections based on a grid system of stakes placed around the trial site. Each sample was sieved, air dried, then mixed.

A $1 \mathrm{~g}$ subsample of the dried soil was then placed in a vial, $10 \mathrm{ml}$ of sterile water was added and the suspension mixed using a vortex shaker. A $1 \mathrm{ml}$ subsample of this solution was then added to $9 \mathrm{ml}$ of sterile water then mixed again with the vortex shaker. This process was repeated once more to give a $10^{-2}$ serial dilution. A $0.5 \mathrm{ml}$ sample of the $10^{-2}$ serial dilution was pipetted onto plates of a selective medium (cornmeal agar (17 g/ litre) containing ampicillin $250 \mathrm{ppm}$, pimaricin $10 \mathrm{ppm}$ and rifampicin $10 \mathrm{ppm}$ ) using a micro-pipette, and incubated at $22^{\circ} \mathrm{C}$ for 5 days. All of the fungal colonies on each plate were then identified, counted and recorded.

\section{Statistical methods}

For Pythium, Phytophthora and 'other (unidentified) fungi', the number of colony forming units (CFU) from the samples for each plot were log-transformed, in order to stabilise the variance ( 0 was replaced with 0.5 to enable the log-transformation) before analysis of variance. The correlation between consecutive observations was not high, so a 'split-plot over time' structure was used, rather than any more complex repeated measures analysis. Fusarium infestation was rare, making the distribution of the number of CFU very skewed. A logistic regression was used to investigate how the presence or absence of Fusarium varied with time and treatment.

\section{RESULTS}

Fungal level varied considerably over time ( $\mathrm{P}<0.001$ for all four species), with all the treatments following broadly the same pattern (date $\mathrm{x}$ treatment interaction $\mathrm{P}>0.8$ for Pythium and Fusarium, $\mathrm{P}=0.2$ to 0.3 for Phytophthora and other fungi). Figure 1 illustrates the fungal levels over time for the baseline treatment (Treatment 1 - potato and pasture without metalaxyl). Because of the considerable variations in fungal levels 
over the course of the study, treatment comparisons are presented as mean CFU for the treatment as a percentage of the mean CFU for Treatment 1 at the corresponding date. This is equivalent to back-transforming treatment effects relative to Treatment 1 from the ANOVA on the log-transformed data.

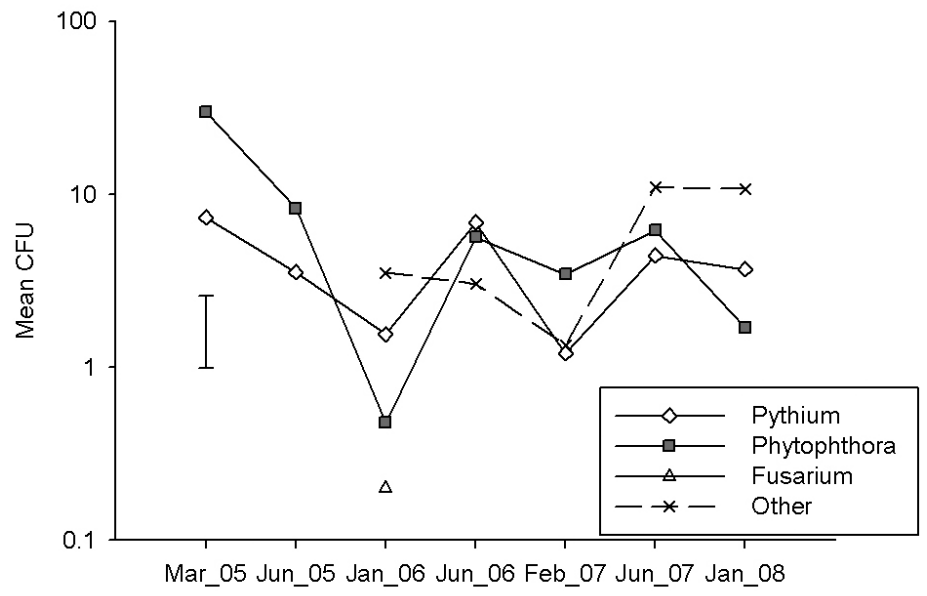

FIGURE 1: Mean CFU (no./g soil sample) for the four fungal categories in Treatment 1 (potato and pasture without metalaxyl) over time. Bar indicates least significant difference for comparing dates within a category.
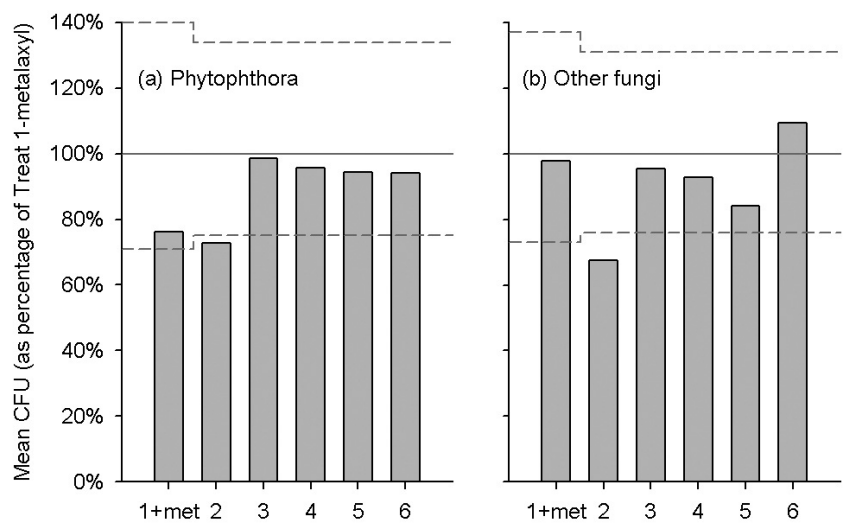

FIGURE 2: Relative CFU for the six treatments (\%, expressed relative to CFU levels for Treatment 1 without metalaxyl, averaged over the seven sampling dates) for (a) Phytophthora and (b) other fungi. Dashed lines indicate threshold for significant difference from Treatment 1 without metalaxyl - the LSD is slightly wider for Treatment 1 with metalaxyl because replication was lower. 
There were no significant differences between the treatments in terms of Pythium levels or incidence of Fusarium ( $\mathrm{P}=0.650$ for Pythium, $\mathrm{P}=0.477$ for Fusarium; data not shown). There was a marginal difference between treatments for Phytophthora ( $\mathrm{P}=0.099$; Fig. 2a), with Treatment 2 (cereal, BQ Mulch and potato) being significantly lower than Treatment 1 (without metalaxyl), while Treatment 1 (with metalaxyl) was marginally lower than Treatment 1 (without metalaxyl) $(\mathrm{P}=0.113)$. Treatment 2 (same rotation as Treatment 4, but with BQ Mulch) had significantly lower levels of Phytophthora than Treatment $4(\mathrm{P}=0.025)$. There was also a significant difference for other (unidentified) fungi ( $\mathrm{P}=0.002$; Fig. $2 \mathrm{~b})$, with Treatment 2 significantly better than the Treatment 1 (without metalaxyl). As with Phytophthora, Treatment 2 had lower levels of other fungi than Treatment $4(\mathrm{P}=0.006)$.

\section{DISCUSSION}

After 3 years of field evaluation these results show that Treatment 2 (with BQ Mulch) reduced the level of Phytophthora (compared with Treatment 4 without BQ Mulch), indicating that Brassica spp. in the BQ Mulch may be effective as biofumigants for reducing Phytophthora spp. These results support previous findings that Brassica spp. (BQ Mulch) crop tissues actively suppress soil-borne pathogens, such as clubroot (Cheah et al. 2001) and Aphanomyces root rot (Chan \& Close 1987).

It is interesting to note that metalaxyl gave marginal (not significant) suppression of Phytophthora spp. populations in this trial. Metalaxyl is registered for control of Phytophthora spp. in potatoes, and therefore would be expected to provide much better control of Phytophthora spp. than the present results. Potato growers, especially in Manawatu/Taranaki regions, have been complaining about a loss of effectiveness of metalaxyl. These results support their claims. The reason for metalaxyl's failure to reduce the level of Phytophthora could be due to biodegradation by soil bacteria, as reported by Davison \& Mckay (1999). There is also a possibility that the fungus has developed resistance to metalaxyl because strains of $P$. infestans resistant to this fungicides have been isolated from potato crops (Hartill et al. 1983). However, more work should be carried out to determine the reasons for this loss of effectiveness.

The present results show that there are no significant differences between the treatments in term of Pythium levels and the level of Fusarium is low. Field study will continue to monitor the changes of populations of these fungi after 4-5 years of crop rotation.

Since pink rot and dry rot are major problems on potato and there is no effective chemical treatment to control these diseases, crop rotation with BQ mulch may be an effective management tool. Crop rotations and the use of biofumigant Brassica crops have given effective control of black scurf and stem canker of potato (Larkin \& Honeycutt 2006; Larkin et al. 2003) and have been associated with reductions in soil-borne pests and pathogens when used in crop rotations and as green manures (Larkin \& Griffin 2007).

\section{ACKNOWLEDGEMENTS}

Thanks to Paul and Terry Olsen, who provided the land for the trial; Brent Page, Kevin Sinclair and Ian Mandahl for field trial assistance; and Daniel Park for editing the manuscript. This research was funded by the New Zealand Foundation for Research, Science and Technology.

\section{REFERENCES}

Cheah L-H, Kent G, Gowers S 2001. Brassica crops and Streptomyces sp. as potential biocontrol for clubroot of brassicas. New Zealand Plant Protection 54: 80-83.

Cheah L-H, Marsh AT 2005. Influence of crop rotation on soil-borne diseases of potato crops in Manawatu. New Zealand Plant Protection 58: 315 (abstract only).

Cheah L-H, Marsh AT 2006. Changes in populations of soilborne pathogens after rotational crops following potatoes. New Zealand Plant Protection 59: 370 (abstract only). 
Chan MKY, Close RC 1987. Aphanomyces root rot of pea. 3. Control by the use of cruciferous amendments. New Zealand Journal of Agricultural Research 30: 224-233.

Davison EM, Mckay AG 1999. Reduced persistence of metalaxyl in soil associated with its failure to control cavity spot of carrots. Plant Pathology 48: 830-835.

Hartill WFT, Tompkin GR, Kleinsman PL 1983. Development in New Zealand of resistance to dicarboximide fungicides in Botrytis cinerea, to acylalinines in Phytophthora infestans, and to guazatine in Penicillium italicum. New Zealand Journal of Agricultural Research 26: 261-269.

Larkin RP, Albert M, Griffin TS 2003. Control of soilborne pathogens of potato with Brassica crop rotations. Phytopathology 93: 248.

Larkin RP, Griffin TS 2007. Control of soilborne potato diseases using Brassica green manures. Crop Protection 26: 1067-1077.

Larkin RP, Honeycutt CW 2006. Effects of different 3-year cropping systems on soil microbial communities and soilborne diseases of potato. Phytopathology 96: 68-79.

Vawdrey LL, Martin TM, De Faveri J 2002. The potential of organic and inorganic soil amendments, and a biological control agent (Trichoderma sp.) for the management of Phytophthora root rot of papaw in far northern Queensland. Australasian Plant Pathology 31(4) 391-399. 